\title{
急性頭蓋内圧立進時の脳循環動態に 関する研究
}

\author{
第 $\quad 1 \quad$ 編 \\ 光電法を応用した局所脳血液量測定法の開発 \\ 岡山大学医学部脳神経外科学教室（指導：西本 詮教授) \\ 久山秀幸
}

（昭和 54 年 4 月 16 日受稿）

Key words: Cerebral blood volume, photoelectric method.

\section{I. 緒言}

脳神経外科領域においてしばしば遭遇する急性脳 腫脹の本態に関しては未解決の問題も多く、いまだ 確立された治療方法がない。ここでいう急性脳腫脹 とは、病理形態学的立場から分類された古典的な脳 浮腫や脳腫脹とは全く異なった概念であり，重症頭 部外偤症例などにおいてみられる急激かつ進行性の 脳容種增大によって生じた急性頭蓋内圧元進の病態 にたいし，臨床上から命名されたものである。

Evansら は,かつて, 脳浮腫に対応する古典的脳 腫脹の原因として，vasomotor paralysisによる脳 血管床の增大を重視した。その後, Langfitt らうは, 種々の方法により作成したいわゆる急性脳腫脹にお いて，実際に脳血液含有量の増大していることを証 明し，急性脳腫脹の主たる病態として同様に vasomotor paralysis に基づく脳組織血液含有量の增大を 考えた，すなわち，頭蓋内圧の上昇は，まず脳血流 の娍少を招き，脑組織 hypoxia 队脳組織 $\mathrm{CO}_{2} の$ 蓄積 を生ずる結果，脳血管緊張が低下し，脳血管が搪張 する.この状況下で vasopressor responseによる血 圧上昇がおこれば，脳血液量の増大とともに頭蓋内 圧はさらに上昇し，ここに悪循環が形成され急性脳 腫脹を惹起することとなる。しかし，この急性脳腫 脹の基䃈となる脳血管緊張低下の原因に関しては， 代謝性因子3)や神経性因子")を重視する諸説があり, いまだ結論はえられていない，そこで，急性脳腫脹 の病態を把握し，それを解明してゆくためには，時 々刻々と変動する脳血流量と䏚血液量を同時に連続
測定することが是非とも必要となる。なかでも，脳 血液量を測定する方法としては，従来，各種 radioisotope を用いる方法5),66,77,8),99,10),11),12),131,14),151,16) や

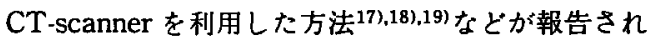
ているが，いずれの方法でも特殊な施設や高洒な機 器, 取扱いの煩雑さなどが問題となる.

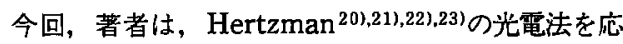
用し，比較的簡単に血色素自体を indicator として 局所脳血液量を連続測定しうる装置を試作した ${ }^{24), 25)}$. 本論文では、本装置の構造ならびに特性について若 干の検討を加え報告する。

\section{II，局所脳血液量測定装置ならびに実験称物}

1. 局所脱血液量測定装置

i ) 光源

光源としては, 直径 $1.4 \mathrm{~mm} の$ 微小電球(浜井電球工 業製 H-0116)であるタングステンランプまたはプロ ジェクターランプ (Rikagakuseiki 製 Master Lux) を用いた，微小電球は液体内でも漏電しないよう透 明なエポキシ系樹脂（セメタイン杜, Hi-super)で絶 縁した，一方，プロジェクターランプからの光は， 直径 $1 \mathrm{~mm} の$ glass fiber (光洋製) にて実験装置に導 いた。なお，微小電球とプロジェクターランプは，

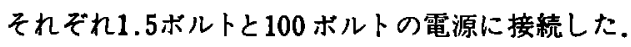

ii）光検出器ならびに脳組織内光吸収量測定装置 光検出には photodiode（シャープ製 SBC 255, SBC 510）または phototransistor（シャープ製 PT 100）を用いた. Photodiode も上記エポキシ系樹脂 にて絶縁し，また phototransistor は内径 $3 \mathrm{~mm}$ の先端 
を閉塞したガラス管内に扱入し，生体内で漏電せぬ よう留意した。次いで,この光検出器を脳表に密着 させ、脳を照射した際の脳組織内光吸収量の強度 (optical absorption, 以下 OA と略す) を測定した. なお, OA 測定に際しては, 光源の明るさ, 増幅器 の感度などを一定にするように注意したが, 測定部 位により多少の動摇はさけ難いため, OAの強度は, 電圧の絶対值ではなく, 光源を on-off したときの電 圧差に対する割合 (relative intensity) として表現し た。なお，OA の測定において，透過光，散乱光， 反射光のいずれを用いるべきかが問題となるので, 基礎実験用としてこれらの3 種類の光を各々区別し て测定し比較検討できるよう glass fiber と光検出器 を分離して使用できるようにしたものを作り sensor Aとした (図 1 ). これに対し, 反射光専用検出用 sensorとして光源と photodiode を一体化したもの

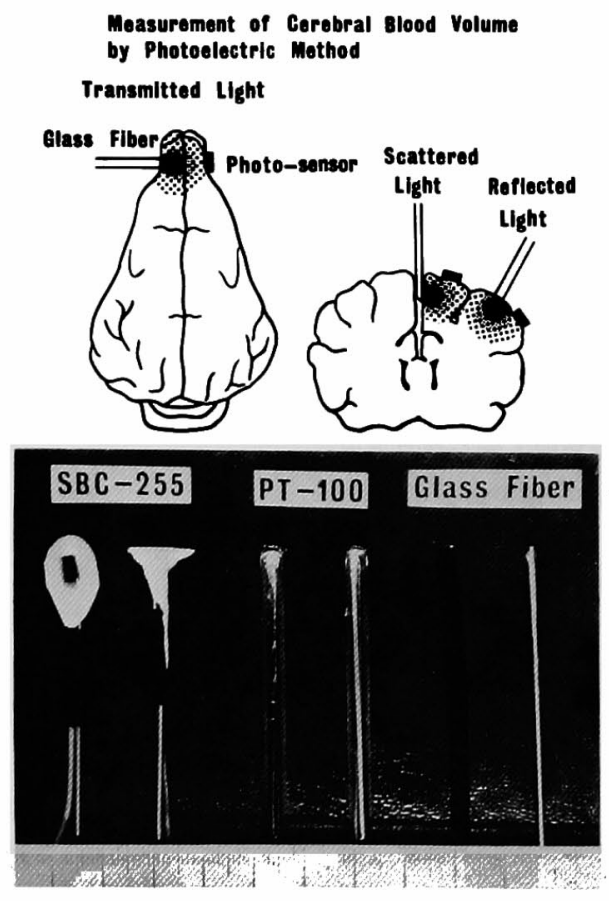

図 1 上図: Sensor A を用いて脳組織内の透 過光, 散乱光および反射光を検出する方法を 示す模式図.

下写真：photodiode (SBC-255),ガラス管内に 挿入した phototransistor (PT-100), glass fiber を示す。

を作成し sensor B とした. Sensor B の光源には微 小電球を, 光検出には gelatin filter (Kodak Wratten gelatin filter No.55) 付き photodiode を使用し,こ の両者を約 $8 \mathrm{~mm}$ 離してシリコンゴムにて一体とし た.さらに、このシリコンゴムの側方に外径 $1.3 \mathrm{~mm}$ の polyethylene tube または polyetylene balloonを 装着し, 圧 transducer (Statham P-37A) を介し頭 蓋内压をも同時測定できるよう工夫した（図 2 ）。
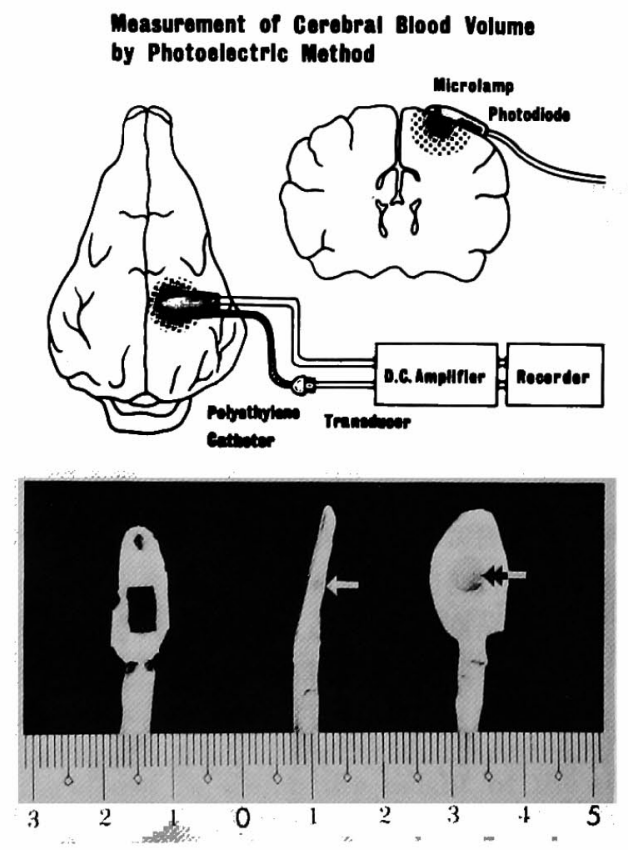

図 2 上図：著者の考案した反射光検出用 sensor (sensor B) の模式図.

下写真：左は sensor B の受光面を示し, 本 sensorに装着した open tipの polyethylene tube $(\leftarrow)$ または polyethylene balloon («) にて頭蓋内圧も測定できる.

Photodiodeまたは phototransistor の光起電力は直流 増幅器（日本光電 RDU-5）を介し, ペン書き直流記録器 (National Pen Recorder VP-6521A または三栄測器, Rectigraph Type 8S) にて連続記録した。

\section{2. 実験動物}

体重 $10 \mathrm{~kg}$ 前後の雑種成犬41頭を用い, 以下表 1 のご とく実験を行なった。

\section{III、装置に関する基碟実験}

1. In vitroにおける基礎実験

i ) 実験方法

（1）脳組織および血液中における光の散乱に関 する実験 
表 1 実験目的および方法

\begin{tabular}{|c|c|c|c|c|c|c|}
\hline 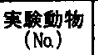 & $\begin{array}{l}\text { 体重 } \\
(\mathrm{kg})\end{array}$ & \multicolumn{2}{|c|}{ 实僌目的およU゙方法 } & 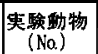 & 俆椞 & 实駿目的拈よU゙方法 \\
\hline 1 & 12.3 & \multirow{4}{*}{\multicolumn{2}{|c|}{ 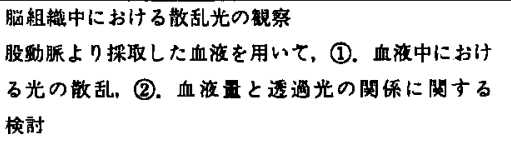 }} & 22 & 8.5 & 下行およU上行大動眽の閉銍 \\
\hline 2 & 9.5 & & & 23 & 10.1 & 上 \\
\hline & & & & 24 & 11.0 & Papaverine hydrochloride 投与 \\
\hline & & & & 25 & 12.6 & 上 \\
\hline $\mathbf{3}$ & 8.4 & \multicolumn{2}{|c|}{ 运組韯の光学特性に関する格即 } & 26 & 9.8 & 同 \\
\hline 4 & 9.5 & \multirow{2}{*}{\multicolumn{2}{|c|}{ 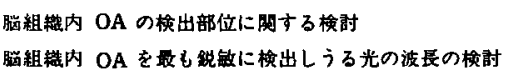 }} & 27 & 8.5 & Papaverine hydrochloride 投与、 Arfonad 投与 \\
\hline $\mathbf{5}$ & 8.2 & & & 28 & 9.5 & 同 \\
\hline 6 & 10.5 & \multirow{2}{*}{\multicolumn{2}{|c|}{ 同 上 }} & 29 & 10.3 & Arfonad 投与 \\
\hline 7 & 10.0 & & & 30 & 8.7 & 同 \\
\hline 8 & 11.4 & \multicolumn{2}{|l|}{ 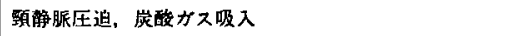 } & 31 & 9.4 & 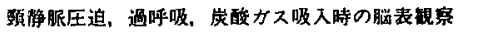 \\
\hline 9 & 8.5 & \multicolumn{2}{|l|}{ 頭橉眼圧迫，過呼吸 } & 32 & 9.8 & 下行かよU゙上行大勁眽閉塞，Papaverine hydro- \\
\hline 10 & 10.5 & 同 & 上 & & & chloride 投与時の檤装视察 \\
\hline 11 & 9.1 & \multicolumn{2}{|l|}{ 過呼吸 } & 33 & 11.5 & \multirow{2}{*}{$\begin{array}{l}\text { 下行およU゙上行大動脈閉塞，炭酸ガス吸入時の腷表钼察 } \\
\text { mannitol 投与 }\end{array}$} \\
\hline 12 & 9.5 & \multicolumn{2}{|l|}{ 過呼吸，宸酸カ又吸入 } & 34 & 12.5 & \\
\hline 13 & 10.5 & 同 & 上 & 35 & 9.5 & 同 \\
\hline 14 & 8.3 & 同 & 上 & 36 & 8.5 & 同 上 \\
\hline 15 & 11.1 & 同 & 上 & 37 & 9.6 & \multirow{2}{*}{ 血流量およU゙へモグロビン酸化度の血液光吸收量にお } \\
\hline 16 & 12.0 & \multicolumn{2}{|l|}{ 炭酸ガス吸入 } & & & \\
\hline 17 & 9.5 & 同 & 上 & 38 & 8.4 & 同 \\
\hline 18 & 12.0 & 同 & 上 & 39 & 10.3 & \multirow{2}{*}{ 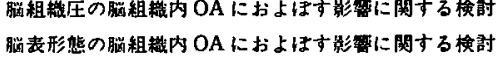 } \\
\hline 19 & 9.1 & \multicolumn{2}{|c|}{ 岸酸カス吸入，Papaverine hydrochloride 投与 } & 40 & 11.0 & \\
\hline 20 & 8.8 & \multicolumn{2}{|l|}{ 下行およU上行大動脈の閉塞 } & 41 & 11.5 & \multirow[t]{2}{*}{ 同上 } \\
\hline 21 & 9.3 & 同上 & & & & \\
\hline
\end{tabular}

脳組織および血液中における光の散乱状態とそれ に対するへマトクリット值の影響を検索する目的で 以下の実験を行なった.

実験動物（No.1）に塩化カリウム飽和溶液20mlを 静脈内投与し, 屠殺した後, 全脳を注意深く取出し, 前額断を加えた. 次いで，脳表に微小電球を密着さ せ，その上を黒布で覆い, Kodak Ektachrome High Speed Film を使用したカメラ (Nikon F) にて脳組 織内における光の散乱状態を撮影記録した（図 3 ).

次に，実験動物（No.2）の大腿動脈より採血した 血液 $100 \mathrm{~m} \ell$ を容量 $100 \mathrm{~m} \ell$ のガラスビーカー内人入れ, ヘパリン1000単位を加えた後よく嫛拌した。プロジ ェクターランプ接続した glass fiber をその先端が 血液表面下 $2 \mathrm{~mm}$ の深さにて光軸が血液表面と平行に なるよう固定し，血液中における光の散乱状態を脑 組織におけると同様な方法で写真撮影した（図4）. さらに，血液に順次，生理的食塩水を加之，へマ卜 クリット值を $51 \%$ ら $38 \%, 24 \%, 14 \%, 7 \%, 5$ \%へ変化させたときの光の散乱状態をも検討した.

(2) 脳組織の光学特性に関する実験

脳組織内の血液量を正確に検出するには, 脳組織 においては吸収されにくく、へモグロビンにのみ特 翼的に吸収きれる波長の光を用いることが望ましい.
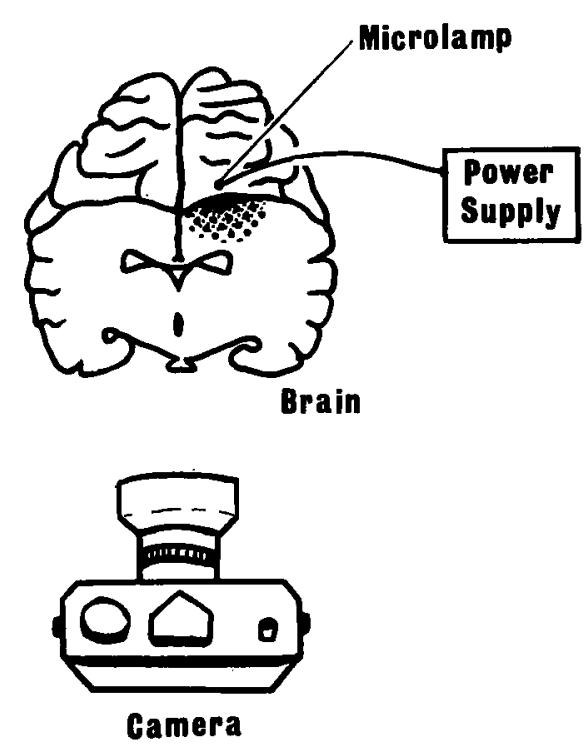

図 3 脳組織内における光の散乱の観察方法. 脳表上の微小電球にて脳を照射し, 脳の切断 面に到達した光を写真撮影した。

そこで，血液を含まない脳組織自体に特有な吸収ス ペクトルが存在するか否かを検討した。 
実験動物（№. 3 ）を(1)と同様な方 法で屠殺した直後，両側総頸動脈に 外径 $2 \mathrm{~mm}$ の polyethylene tube を挿 入し，さらに雨側外頸静脈を切断開 放した. $170 \mathrm{~cm}$ 水柱の加圧下に生理的 食塩水 $1000 \mathrm{~m} \ell$ に全脳を脱血灌流後 脳を摘出し10\%ホルマリン中で 2 週 間固定した. 次いで，パラフィン包 埋の後, 光が透過するのを十分把握 できる厚さ 8〜12 $\mu$ の脳組織標本を 作成し，未染色の状態でその吸収ス ペクトルを分光々度計（島津製作所 UV-200）にて湘定した。

（3）血液量と透過光の関係に関 する実験

血液による光吸収の強度をみるた めに，血液量と透過光の関係を検索 した.

実験動物（No.2）の大腿動脈より

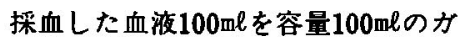

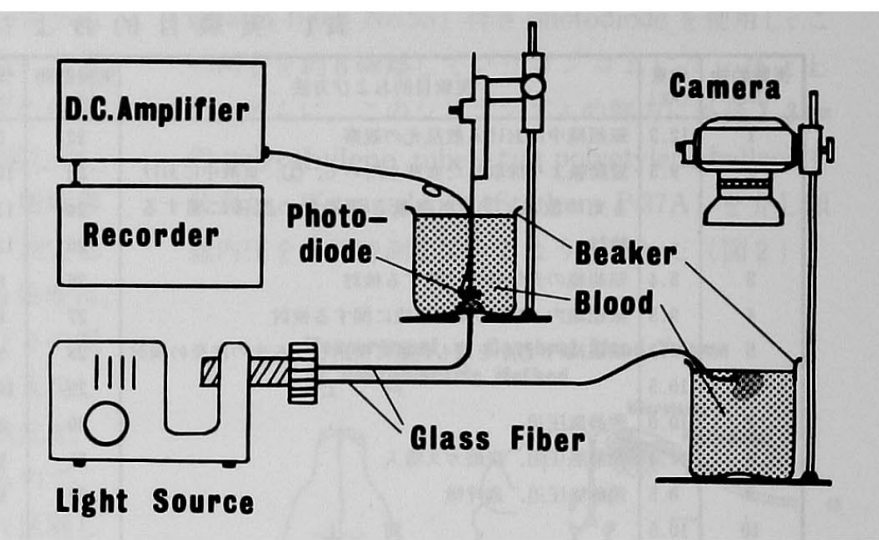

図 4 中図：ガラスビーカー内の血液をビーカーの 外側底面より glass fiberにて照射し，血液内を透過 する光量を，血液中の photodiodeにてその位固をビ 一カーの内側底面より $1 \mathrm{~mm}$ 毎上昇させながら測定し， 血液量と透過光の関係を検索した。

右図：血液中における光の散乱の観察方法. glass fiber の先端をビーカー内の血液表面下 $2 \mathrm{~mm}$, 光軸 が血液表面に平行になるよう設置し，血液面を写真 撮影した。

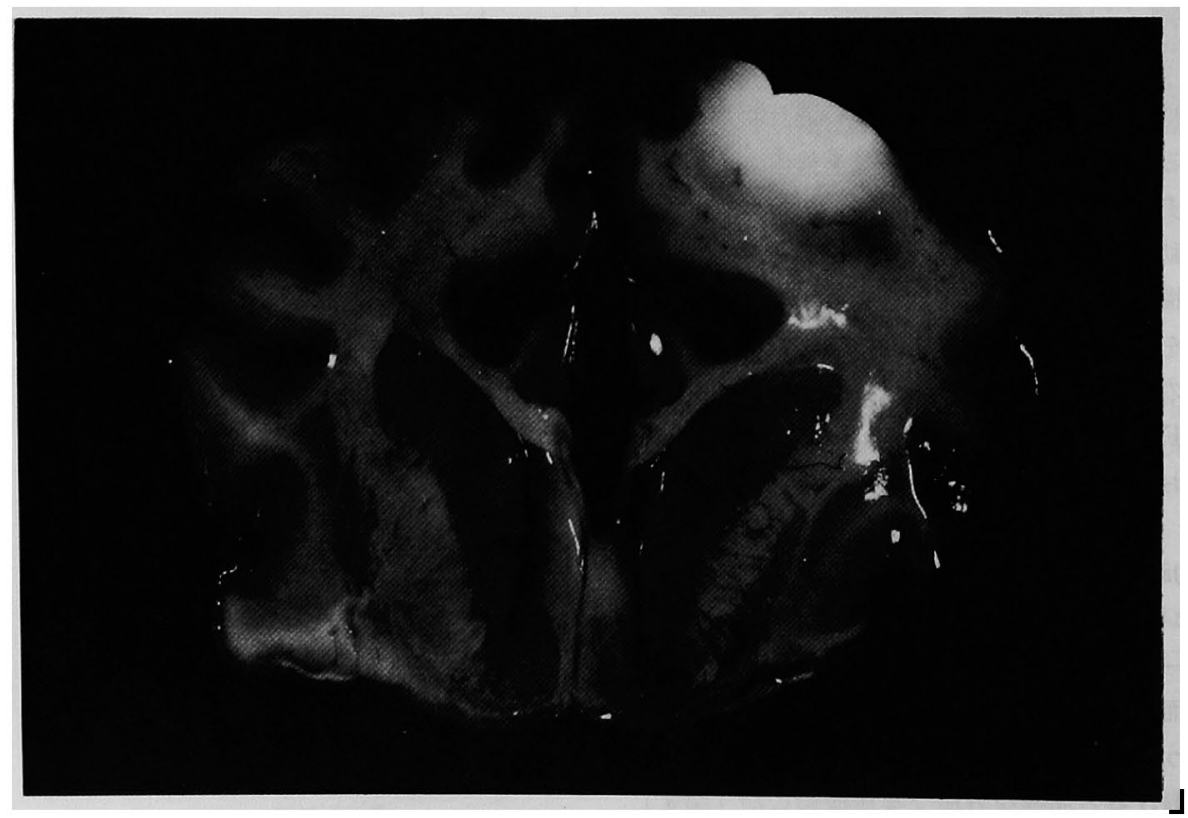

図 5 脳組䢂内では，光は光源を中心として半円状に 散乱した（実験動物No.1 ）.

ラスビーカーに入れ，人パリン1000単位を加えよく 筧䢁した。プロジェクターランプに接続した glass fiberにて,ビーカーの外側底面を照射し，血液内を 透過する光量を，血液中に設置した photodiode に
て、その位置をビーカーの内側底面より $1 \mathrm{~mm}$ 毎上昇 させながら測定した（図 4 ）。
ii ) 実験結果
（1）脳組織および血液中における光の散乱 
脳組織内では, 光は光源を中心に半円状に散乱し た（図 5 ）.血液中においても光は, 光源を中心に半
比例定数を $\alpha$ とすれば, $\mathrm{I}=\mathrm{I}_{0} \mathrm{e}^{-\mathrm{c} a \mathrm{~d}}$ の関係式が成 立した。

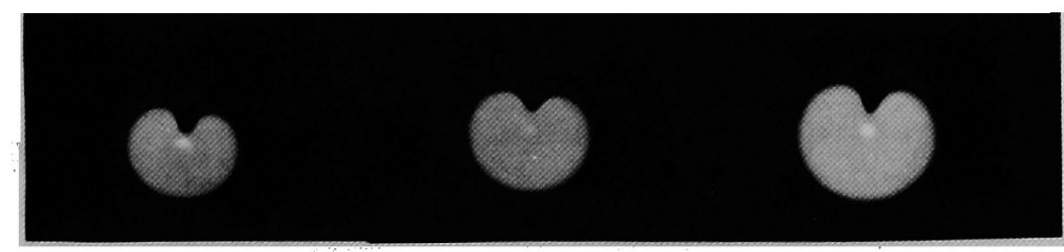

Ht $51(\%) \quad$ Ht $38 \quad$ Ht 24

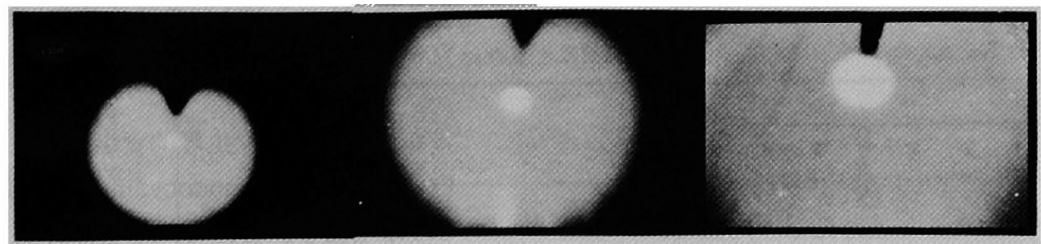

\section{Ht $14 \quad$ Ht $7 \quad$ Ht 5}

图 6 血液中において, 光は光源を中心とし て半円状に散乱し，この散乱光はへマトクリ

ット值が小さくなるにつれ增強した。

円状に散乱し，この散乱光は血液のへマトクリ ット值が小さくなるほど強くなった（図6）.

(2) 脳組織の光学持性

脳組織, へモグロビン, 各種フィルター (gelatin filter と赤外フィルター) の透光 スペクトルおよび photodiode の感度特性 を示したものが図7である。なお、ここでへ モグロビンの透光スペクトルは, 上代ら監修 による血色素の生理と臨床 ${ }^{26)}$ より転載したも のである。

脳組織自体には, 特別な吸収スペクトルは 存在しなかった. gelatin filter は $520 \mathrm{~m} \mu$ 前後 と $680 \mathrm{~m} \mu$ 以上を, また赤外フィルターは 680 $\mathrm{m} \mu$ 以上のみの波長の光を透過した. 一方, 酸 化・還元へモグロビンの吸光曲線は $520 \mathrm{~m} \mu$ お よび $680 \mathrm{~m} \mu$ 以上の波長域ではほほ一致した.

\section{（3）血液量と透過光の関係}

血液量と透過光との間では, 溶液において 溶液層の厚さと濃度との間に成立する Lambert-Beerの法則が成立した（図 8 ). すなわ ち, 厚さ $\mathrm{d} の$ 溶液層に照射した光の強さを $\mathrm{I}_{0}$, 通過した光の強さをIとし, 溶液の濃度を $\mathbf{c}$,

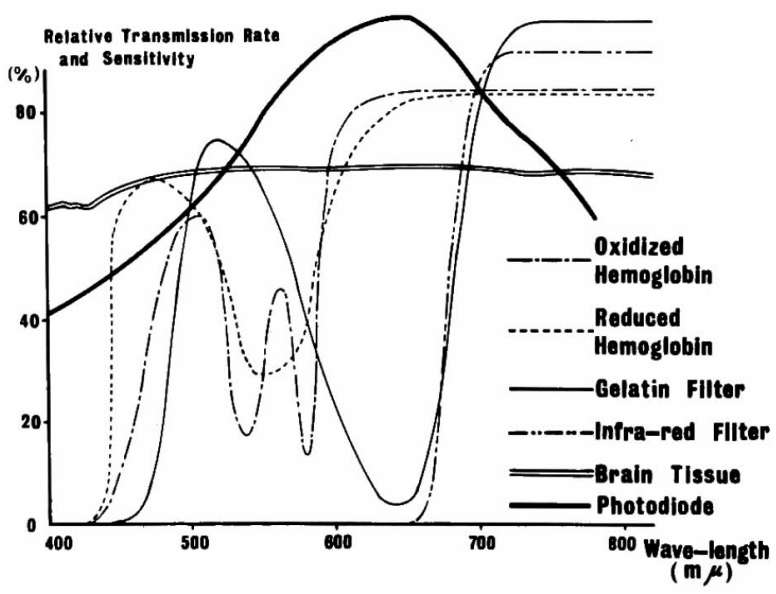

図 7 脳組織, へモグロビン, 各種フィルタ 一の透過率および photodiode の感度特性を示 す。なお，へモグロビンの透光スペクトルは 上代ら ${ }^{26)}$ のデータより転載したものである。

\section{In vivoにおける基礎実験}

脳組織内 OA をより的確に検出しうる測定方法と 光の波長域を検索する目的で以下の実験を行なった。

i ) 実験方法 


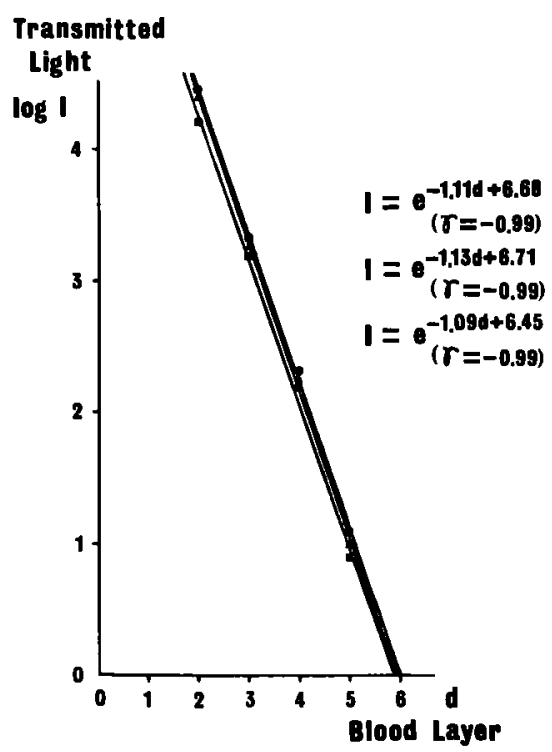

図 8 血液量と透過光との関係

体重 $10 \mathrm{~kg}$ 前後の雑種成犬を用い（表 1 ), ketamine hydrochloride $5-10 \mathrm{mg} / \mathrm{kg} の$ 筋肉注射による麻酔後, 気管内扱管を行なった。次いで succinylcholine chlorideにて非動化し，室内空気を用いたレスピレー ター(ACOMA 製 respirator AR-300) にて生理的 調節呼吸に保った。また実験中の輸液として，生理 的食塭水を一定の速度 $(1.5 \mathrm{ml} / \mathrm{min})$ で一側大腿静脈 内人点滴注入した. 実験動物NO. 4 の右上腕動脈を露出 し, 外径'2 mmの polyethylene tube を, 先端が腕頭動 脈内で総頸動脈分岐部近くに位置するよう扦入した。 次いで, 頭部を東大脳研型脳定位固定装置に固定し, 頭部正中に皮席切開を加え，側頭筋を㐜離したのち， 西側前頭部にそれぞれ直径 $1.2 \mathrm{~cm}$ の穿孔を，また，右 頍頂部から正中部にかけ，幅 $1.5 \mathrm{~cm}$ 長さ $3 \mathrm{~cm}$ の長方形 の開頭を行なった，脳組織内 $\mathrm{OA}$ は sensor A を用 い, 透過光，散乱光，反射光をそれぞれ区別し測定 した，透過光は，両側前頭部の硬膜を切開後，左前 頭部に glass fiber を, 右前頭部に光検出器を、いす れも脳表に密着するよう設置し測定した。この際，

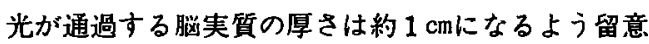
した. 散乱光は硬膜を切開後, 先端が直角に屈曲し た直径 $1 \mathrm{~mm} の$ glass fiber $\mathrm{falx}$ に平行に $5 \mathrm{~mm}$ 抻入し、 脳表上に設置した光検出器にて測定した，反射光は glass fiber と光検出器をそれぞれ $8 \mathrm{~mm}$ 離し, 脳表上 に密着させて測定した（図 1 ）。なお,glass fiber と 光検出器は两者の距離が変わらないようともに頭蓋外
で固定し，外部からの光を遮断するため頭部を黒布 で覆った，次いで，右上腕動脈より生理的食塩水 3 $\mathrm{m} \ell$ または $0.25 \%$ indocyanine green 溶液 $0.5 \mathrm{~m} \ell$ を注入 し, 透過光，散乱光，反射光のうち，いずれが最も 鋭敏に脳組織内 $\mathrm{OA}$ の変化を表現しうるかを検討した。

次に, 実験動物No 5,6 を用い, 上記と同様な実験 設定の下に; 光の波長域を変え, 右上腕動脈より生 理的食塩水 $3 \mathrm{~m} \ell$ one shot で注入したさいの OA の変化を透過光と反射光を検出することにより検討 した. 光の波長域を変えるには白色光の他に各種】 イルター（赤外フィルターの Kenko R68, gelatin filter, 光洋製 $520 \mathrm{~m} \mu$ 干涉フィルター) を用い，各々 の光について，OAの基線が安定したことを確認した うえで生理的食塩水を 5 ～回くりかえし注入した.

ii ) 実験結果

右上腕動脈より生理的食塩水を注入すると脳組織 内 $\mathrm{OA}$ は減少し, indocyanine greenを注入すると OA は增加し, これらの変化は透過光, 散乱光, 反 射光のいずれを検出してもほぼ同様な変化を示した (図 9 ).

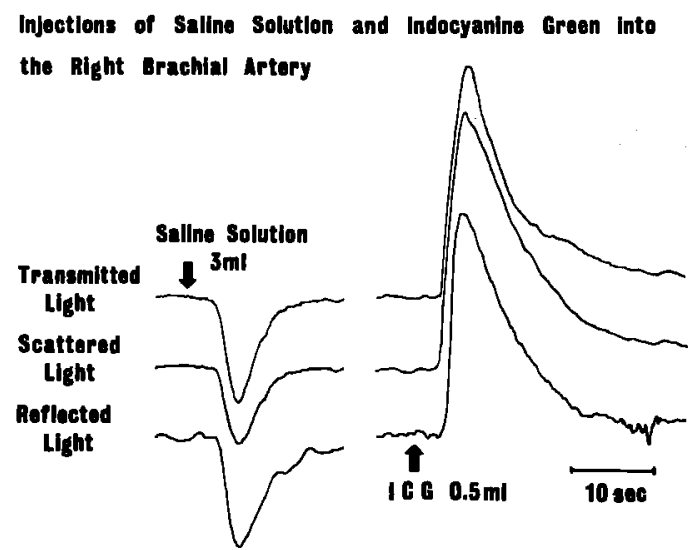

図 9 右上腕動脈より生理的食塩水を注入す ると脑組織内 OA は減少し, indocyanine green を注入すると脳組織内 OA は増加し, これらの変化は透過光, 散乱光, 反射光のい ずれを検出しても同様な変化を示した（実験 動物No. 4 ).

次に, 右上腕動脈より生理的食塩水 3 吼を注入し た際の relative intensityは, 頭頂部の反射光におい て，白色光では $5.2 \pm 0.5 \%$ 変化率を示し, 赤外フ イルター光5.3土0.8\%, gelatin filter $7.5 \pm 0.9 \%$, $520 \mathrm{~m} \mu$ 千涉フィルター光20.4 $44.9 \%$ で, $520 \mathrm{~m} \mu$ 千 涉フィルター光が最も大きい変化率を示した.また， 
前頭部の透過光においても，千涉フィルター光の relative intensity が最も大きかった（表 2 ）.しかし， 干涉フィルター光は脳組織内では減衰しやすく，增
出することができるものと思われた．また血液量と 透過光の間に Lambert-Beer の法則が成立したこと は，極くわずかな血液量の変化をも比較的大きな光

表 2 各種フィルター光と relative intensity

\begin{tabular}{|c|c|c|c|}
\hline & dog No & $\begin{array}{l}\text { parietal region } \\
\text { reflected light } \\
\text { (relative intensity) }\end{array}$ & $\begin{array}{c}\text { frontal region } \\
\text { transmitted light } \\
\text { (relative intensity) }\end{array}$ \\
\hline \multirow{3}{*}{$\begin{array}{l}\text { white } \\
\text { light }\end{array}$} & 5 & $\begin{array}{l}4.3(\%) \\
5.0 \\
5.4\end{array}$ & $\begin{array}{l}4.3(\%) \\
4.3 \\
3.3\end{array}$ \\
\hline & 6 & $\begin{array}{l}5.4 \\
5.9 \\
5.2\end{array}$ & $\begin{array}{l}3.7 \\
4.2 \\
4.2\end{array}$ \\
\hline & \multicolumn{2}{|r|}{$5.2 \pm 0.5$ (mean $\pm S D)$} & $4.0 \pm 0.4($ mean $\pm S D)$ \\
\hline \multirow{3}{*}{$\begin{array}{l}\text { infra-red } \\
\text { filter } \\
\text { light }\end{array}$} & 5 & $\begin{array}{l}4.3 \\
4.6 \\
5.7\end{array}$ & $\begin{array}{l}3.4 \\
3.8 \\
4.3\end{array}$ \\
\hline & 6 & $\begin{array}{l}5.7 \\
6.4\end{array}$ & $\begin{array}{l}4.2 \\
4.3\end{array}$ \\
\hline & & $5.3 \pm 0.8$ & $4.0 \pm 0.4$ \\
\hline \multirow{3}{*}{$\begin{array}{l}\text { gelatin } \\
\text { filter } \\
\text { light }\end{array}$} & 5 & $\begin{array}{l}8.1 \\
6.6 \\
7.2\end{array}$ & $\begin{array}{l}4.9 \\
3.5 \\
3.3\end{array}$ \\
\hline & 6 & $\begin{array}{l}8.6 \\
8.6 \\
6.6 \\
6.6\end{array}$ & $\begin{array}{l}4.5 \\
4.1 \\
4.1 \\
4.5\end{array}$ \\
\hline & & $7.5 \pm 0.9$ & $4.1 \pm 0.5$ \\
\hline \multirow{3}{*}{$\begin{array}{c}\text { interference } \\
\text { filter } \\
\text { light }\end{array}$} & 5 & $\begin{array}{l}28.0 \\
13.0 \\
20.0\end{array}$ & $\begin{array}{r}10.6 \\
5.6 \\
8.9\end{array}$ \\
\hline & 6 & $\begin{array}{l}18.5 \\
22.5\end{array}$ & $\begin{array}{l}5.6 \\
5.6\end{array}$ \\
\hline & & $20.4 \pm 4.9$ & $7.3 \pm 2.1$ \\
\hline
\end{tabular}

幅器の感度を $\mu \mathrm{V}$ のrangeにする必要があるため, OA の基線変動が著しく長時間の連続測定は困難であ った.

3. 小括

脳組織中でも血液中でも光は光源を中心として半 円状に散乱ししかもへマトクリット值が低下した 場合においても脳組織内 OA は, 透過光, 散乱光, 反射光のいずれを用いても検出しえた。光検出器に gelatin filter を用いれば, $680 \mathrm{~m} \mu$ 以上の波長の光を よく透過する．この波長域の光は脳組織をよく透過 し，血液には吸収されやすい上に27，photodiode $の$ 分光感度特性も $650 \mathrm{~m} \mu$ で最も高いことから（図 7 ）, このフィルターを用いれば安定した状熊で OAを検
の変化として表示しうる可能性を示している.

In vivoの実験では, 透過光, 散乱光, 反射光とも に同様の変化を示し，OAはいずれの光を検出して もとらえうることがわかった。しかし，このうち透 過光と散乱光を実際に検出するには，イヌの脳の形 態から測定部位が前頭部か大脳縦裂周辺部に限られ てしまうのに反し，反射光を用いればあらゆる部位 の脳表で OAの測定が可能となる。

以上の結果を綕括した上で，以下の in vivo の実 験では特別な場合を除き， sensor Bを用い，もっぱ ら反射光を検出することにより OA 測定した。

この sensor B では，微小電球と photodiode を厚 さ $2 \mathrm{~mm}$ のリコンゴムで一体としてあるため, 光源 
の温度上昇も少なく，また容易に硬膜下腔へ挿入し， 脸表へ密着させることができる，そのため，脳の搏 動や動摇により sensor と脳組織との間にずれを生じ たり，脳損傷を生ずることなく测定を行なうことが 可能であり, 脳への圧迫や光源と光検出器の固定方 法によって生ずる artifactを最小限にとどめえた。 したがって, 頭蓋内圧六進時にも比較的安定して OAを連続記録することも可能であった。

\section{N 本 実 験}

\section{1 、実験方法}

i ）実験動物ならびに測定装置

（1）奏験動物，麻酔方法，呼吸管理および輸液 体重 $10 \mathrm{~kg}$ 前後の雑種成犬を用い(表 1)，而の 2 の ) に述へたと同様な麻酔方法，呼吸管理，輸液方法に よった。

（2）局所脳血流量測定

局所脳血流量の測定は, heat clearance 法 (Shincorder CTE 202）を用い2, thermocouple probe を 左頭頂部に作成した直径 $2 \mathrm{~mm} の$ 穿頭孔から硬膜を穿 通し脳表より $5 \mathrm{~mm}$ の梁さに刺入固定した。この probe は外径0.6m と非常に細く、刺入による脳損㒐も 少なく，かつ連続測定できる利点がある。

(3) 血液がス分析装置

Radiometer 社製の BMS3, MK2 Blood Microsystem そ PHM72, MK2 Digital Acid-Base Analyzer を用い, 実験動物より動脈血を採取後，直ちに 動脈血中の酸素分圧 $\left(\mathrm{PaO}_{2}\right)$, 炭酸ガス分压 $\left(\mathrm{PaCO}_{2}\right)$, $\mathrm{pH}$ を測定した。

(4) 頭蓋内圧测定

右頭頂部硬膜下腔へ挿入した sensor B，または経 皮的に大槽内へ刺入した22ゲージ針に圧 transducer (Statham P-37A) を接続し測定した。

(5) 血圧測定

一側大腿動脈または上腕動脈内一外径 $2 \mathrm{~mm} の \mathrm{pol}$ yethylene tubeを挿入し, 圧 transducer (Tōyō Meas. 製 MPU) を介し測定した.

(6) 呼吸回数測定

呼吸回数の測定には，thermistor respirometer （三栄測器製，呼吸用ピックアップ E-068）を用い, $こ の$ thermistor probe $を$ respirator の呼気流出口に 接綂し測定した。

ii）脳血管床容積および脳組織中水分量の脳組 織内光吸収量におよはす影響

実験動物No. 7 からNo.36の30頭を用いた，一側大腿
動脈へ polyethylene tube を挿入し動脈血圧を測定し た。また右上腕動脈に cannulation し，下行大動脈 閉塞時の血圧測定として使用した。ざに，一側大 腿静脈にも cannulation $し$, 生理的食塭水の点滴注 入を行なうとともに，必要に応じ各種薬侴をこれよ り静脈内投与した。

次に，頭部を固定装置に固定し，右頭頂部に burr hole を穿ち, 硬膜を切開後 sensor B を硬膜下腔に 挿入し, 脳組織内 $O A$ を測定した。脳血流は左頭頂 部にて測定し, 頭蓋内压, 呼吸回数と同時記録した （図10）。お穿孔部は,Adhesive（Kerr製，Permlastic）を塗布し，ポリサルファイド系合成ゴム(GC製，

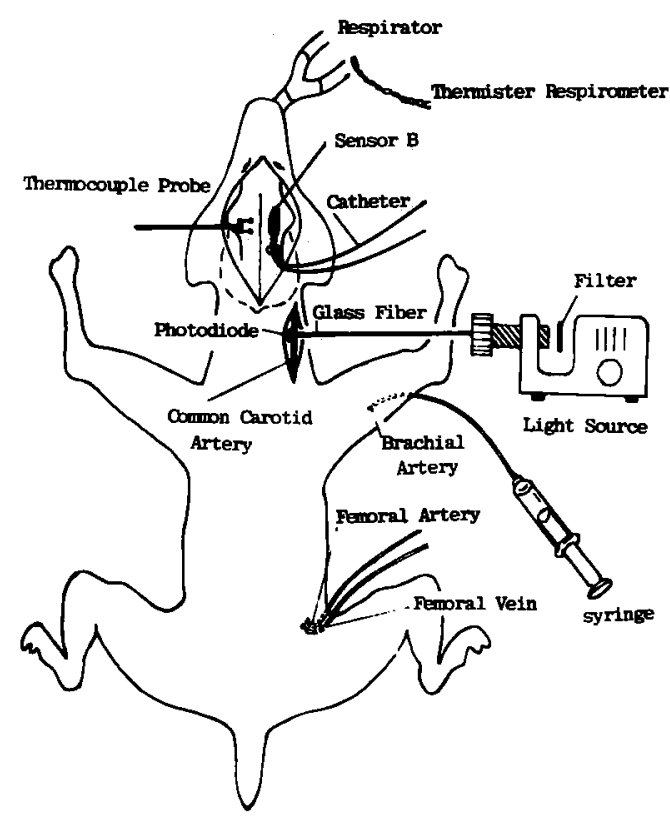

図10 実験方法の模式図

Sūrflex F)を立てんすることにより頭蓋内腔をwater tightに閉鎖後，頭部を黒布で覆った。

すべての生理的条件が安定したのち，脳血管床容 䅧の変動をきたす各種負荷試験として，頸静脈圧迫 （首に巻いた血圧測定用 cuff を約 $50 \mathrm{~mm} \mathrm{Hg}$ まで加圧す る)， 2 分間の $10 \%$ 炭酸ガス吸入， 3 分間の過呼吸， 開胸後の下行および上行大動脈の鉗子による閉塞, Papaverine hydrochloride $(3.0 \mathrm{mg} / \mathrm{kg})$, Arfonad $(0.5$ mg) の静脈内投与を行ない, そのときの脳組織内 $\mathrm{OA}$ の変化について検討した。

さらに，脳血管床容積が変動したときの隠表血管 を観察するために，実験動物№.31，32，33を用い, 
左頭頂部に直径約 $3 \mathrm{~cm}$ の開頭を行ない, 硬膜を切開 反転後，上記と同様な負荷試験を行なったさいの脳 表を手術用顕微鏡にて10倍に拡大し観察した。

なお，いずれの場合も各種負荷試験は，30分以上 の間隔をおいて各生理的パラメーターが安定したの を確認後行なった。

次に，実験動物No.34，35，36を用い，脳組織内 $O A$ と腮組織中水分量の関係を検索するために，20\% mannitol $150 \mathrm{~m} \ell$ を 10 15分間で静脈内に点滴注入し たとき生ずる OAの変化を測定した。

iii）血流量およU゙へモグロビン酸化度の血液光 吸収量におよぼす影響

腦血流量とへモグロビン酸化度が変化した場合に 生ずる血液光吸収量の変動を検索するために実験動 物№.37，38を用いた. 右総頸動脈を露出し, 血管径 が変らないよう注意して, 直径 $1 \mathrm{~mm} の$ glass fiber の 先端と photodiode を血管壁に密着固定した. gelatin filter または郝フィルターを透過した光をこの glass fiber を介し総頸動脈へ照射し，その透過光を対側に おいた photodiode (Sensor A) で検出した（図10). 次いで，10\%炭酸がスを 2 分間吸入し，そのときの 総頸動脈内 $O A$ について検討した. なお, 腷血流量, 䏚組織内 OA，頭蓋内庄および血圧は, Nの1のii）と同
を用い，右前頭々頂部を大きく開頭し，硬膜を切開 後 sensor B を脳表に設置し，その上を黒布で覆った。 この sensor の脳に対する圧を上昇させるために, sensor 上に順次 $10 \mathrm{~g}, 20 \mathrm{~g}, 40 \mathrm{~g}$ の鏵を置き，このときの $\mathrm{OA}$ を測定した，次いで，塩化カリウム飽和溶液20

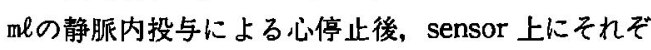
れ $20 \mathrm{~g}$ と $40 \mathrm{~g}$ の鏵を設置した場合の OAについても 検討した.

さらに, sensor下面の脳回, 脳拝などの脳表形態 の差により，OAの测定值がいかに変化するかを検 索した. 実験動物No.40，41の右頭頂部に burr hole を穿ち，硬膜を切開後 2 個の sensor B を，右前頭 部では脳回上に，右頭頂側頭部では脳瑇上に設置し， 2 分間の10\%炭酸ガス吸入ならびに Papaverine hydrochloride $(20 \mathrm{mg})$ 投与時の OA を同時記録した (図11).

\section{2. 䒠験結果}

i ) 脳血管床容積および脳組織中水分量の脳組 織内光吸収量におよばす影響

脳組織内 OA は, 心搏動ならびに呼吸運動と一致 した変動を示し, 頭蓋内压ともよく同期して変化し た、頸静脈を圧迫すると, 脳血流量は減少したが, OA と頭蓋内圧は増加した（図12）.10\%炭酸がス吸

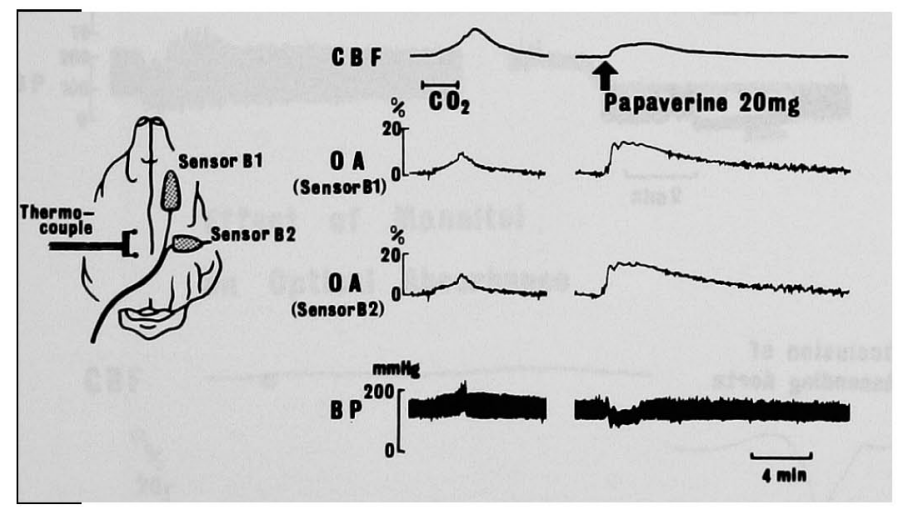

图11 右前頭部と右頭頂側頭部の 2 か所に sensor B を設置し（左図）, 10\%炭酸ガス吸入と Papaverine hydrochloride $の$ 静脈内投与を行なうと, いずれの sensor で測定した OA を 同椂な変動を示した（右図，実験動 物No.40).

㥞な方法により同時記録し，血液ガス漛度は大腿動 脈より採血し血液ガス分析装置にて測定した。

iv) Sensor 下面の脳組織圧およひ脳表形態の脳 組織内光吸収量におよはす影響

Sensor 下面の脳組織圧が上昇したときのOA の 変化を検討する目的で, 生体脳と死体細において sensor B を脳表にあて圧迫を加えた. 実験動物 No.39
入では, 脳血流量, 頭蓋内压, $\mathrm{OA}$ はもに增加し, 吸入を中止するともとのレベルに復した，過呼吸で はOA と頭蓋内圧は減少し, 過呼吸中止により過呼 吸前值に復帰した（図13）.下行大動脈を閉塞し、脳 灌流圧を上昇するとOA は增加し, 閉塞を解除する と次第に閉塞前のレベルにもどった。上行大動脈の 閉塞と同時に OAは急激に減少し, 閉塞を解除する 


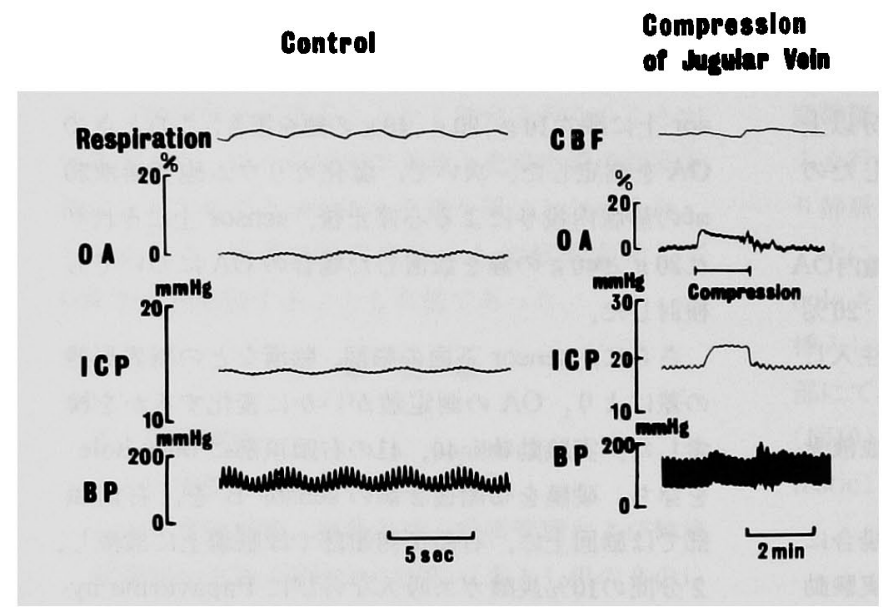

図12脳組織内 OA は, 心搏動, 呼吸 運動と一致した変動を示し, 頭蓋内圧 とも同期して変化した（左図，実験動 物NNo.7）頸静脈を圧迫すると脳血流は 減少したが，OA と頭蓋内压は增加し た（右図，実験動物NNo.8).

$\mathrm{CO}_{2}$ Inhalation

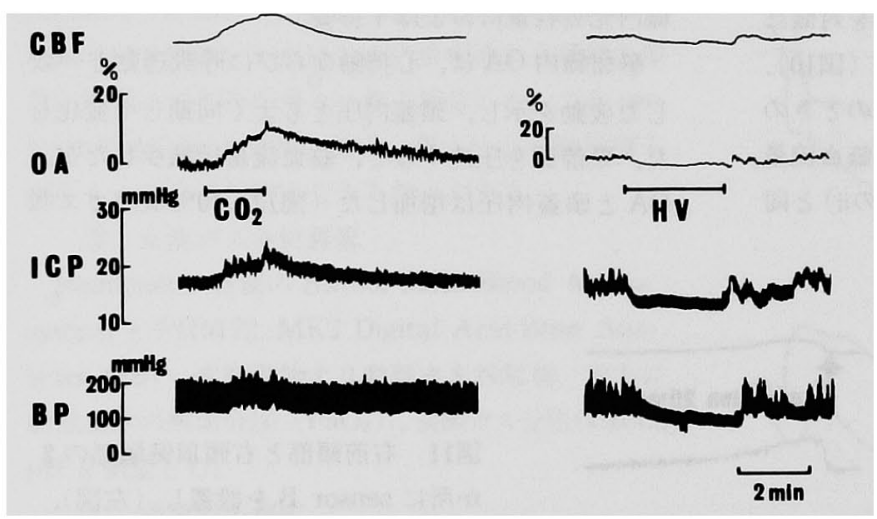

図13 10\%炭酸ガス吸入により，脳血 流量. OA, 頭蓋内压はともに増加し(左 図, 実験動物No.15), 過呼吸ではそれら は減少した（右図，実験動物№.12）.
Occlusion of Descending Morta

CBF<smiles>CCCCCC(C)(C)CCCC</smiles>
clip on off

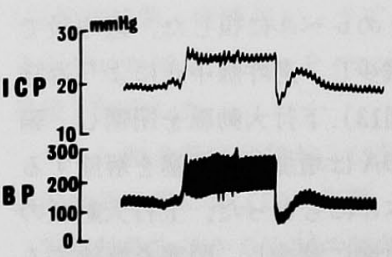

Ocelusion of Ascending Morta<smiles>[Te][Te]</smiles>
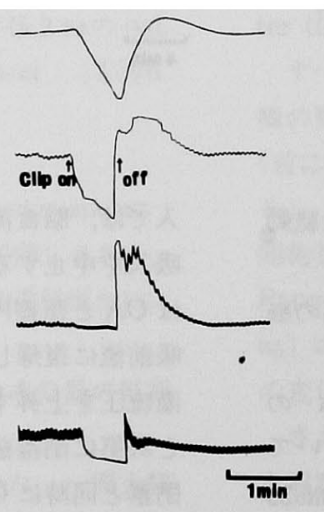

図14 下行大動脈を開塞すると脳血流 量, OA, 頭蓋内圧は增加し（左図, 実験動物No.21),上行大動脈の閉塞によ クそれらは減少した（右図，実験動物 No.22). 
と一過性の増加後次第にもとに復した（図14）. Papaverine hydrochloride を投与すると血圧は多少低下 するか，OA と頭蓋内压は增加し，Arfonad $の$ 点滴 静注では急激な血圧低下とともに OA と頭蓋内圧は 隇少した（図15）.

各種負荷試験による脳表血管の変化としては, 上 行大動脈の閉塞時に脳表の薈白化がみられ, 脳血管 は狭小となったが（図16）,他の負荷試験では明確な 変化は認められなかった。

Mannitol 投与では全例において，頭蓋内圧は次 第に低下するが OAはほとんど変化しなかった（図 17).

ii）血流量扰よU゙へモグロビン酸化度の血液光
吸収量におよぼす影響

2 分間の $10 \%$ 炭酸ガス吸入により, $\mathrm{PaCO}_{2}$ は15一 $17 \mathrm{~mm} \mathrm{Hg}$ 増加し, $\mathrm{PaO}_{2}$ は 5-7 mm Hg 減少した。 その 結果, 脳血流量は增加したが総頸動脈内 OAはいず れのフィルターを用いても変化しなかった（図18).

iii）Sensor 下面の脳組織圧および脳表形態の脳 組織内光吸収量におよばす影響

Sensor B 上の錘を大きくするにつれ，生体脳では OA は減少したか，死体脳では変化しなかった（図 19).

次に,脳回と脳溝上に sensor B を設置後，10\%炭 酸ガス吸入と Papaverine hyddrochloride の投与を行 なったが，そのいずれも同様な OAの変化を示した (図11).
Intravenous Administration of Papaverine and Arfonad

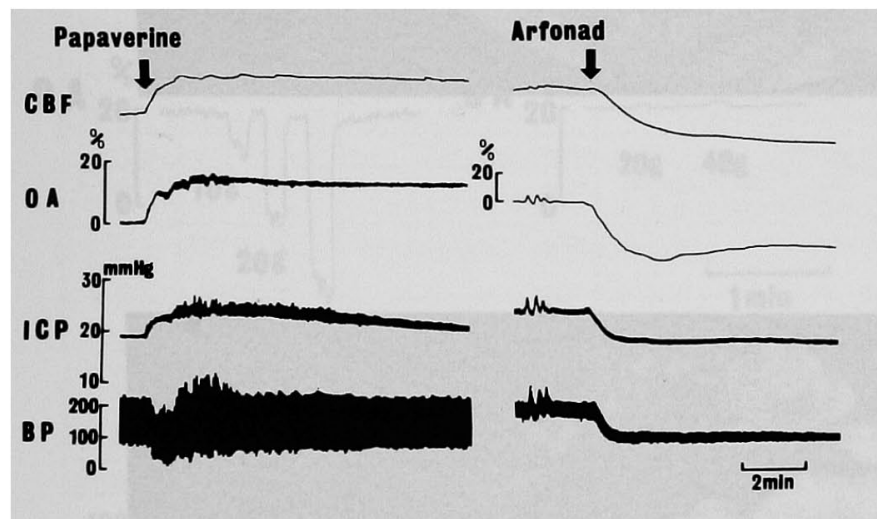

Effect of Mannitol

on Optioal Absorbanee

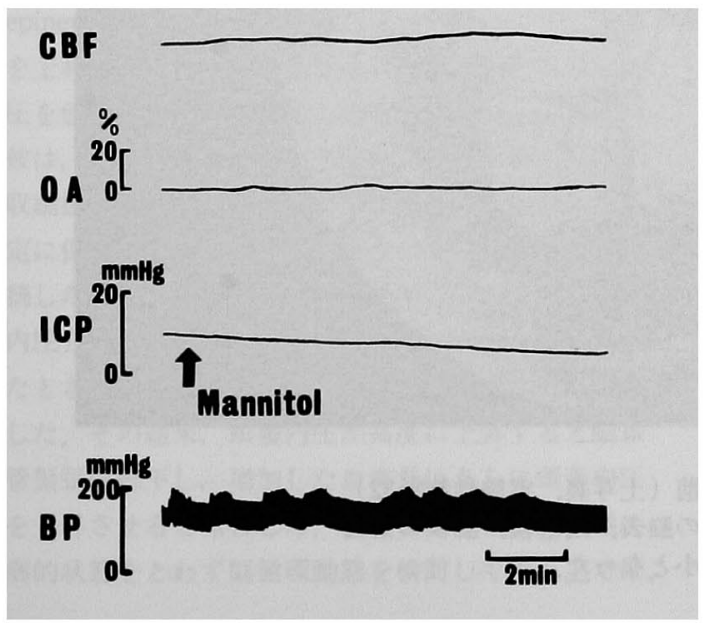

図15 Papaverine hydrochloride $の$ 静 脈内投与で, 脳血流量, OA, 頭蓋内圧 はともに增加し(左図，奏験動物No.24）， Arfonadの点滴静注で减少した（右困, 実験動物No.30).

図17，Mannitolの点滴静注で頭蓋内圧 は次第に低下するが，脳組織内 OA はほ ぼ一定であった（実験動物No.35）. 

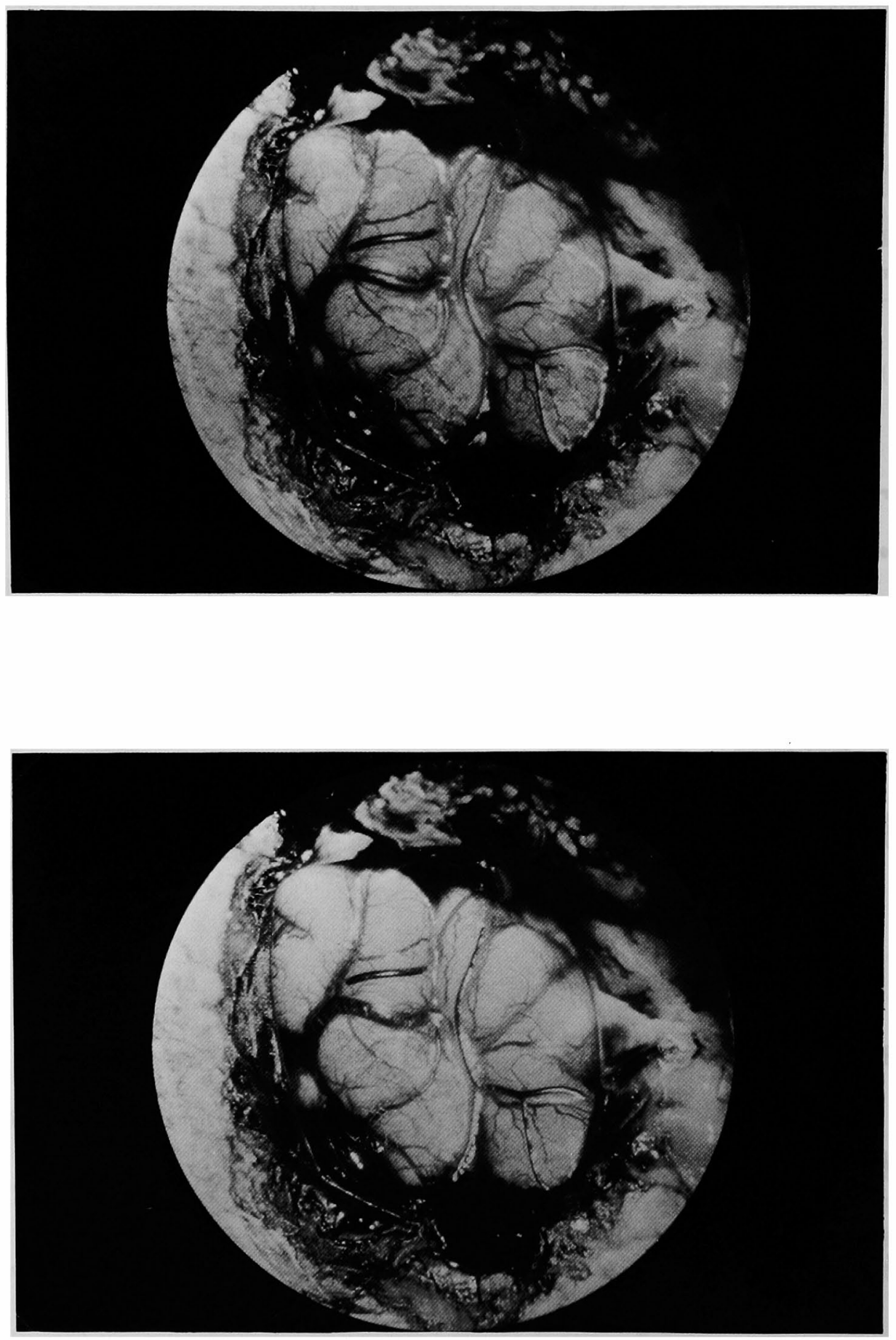

図16 上行大動脈の閉塞前 (上写真, 実験動物NNo.32) および閉塞後 (下写真) の脳表. 閉塞後, 脳表の蒼白 化がみられ，脳血管は狭小となった。 


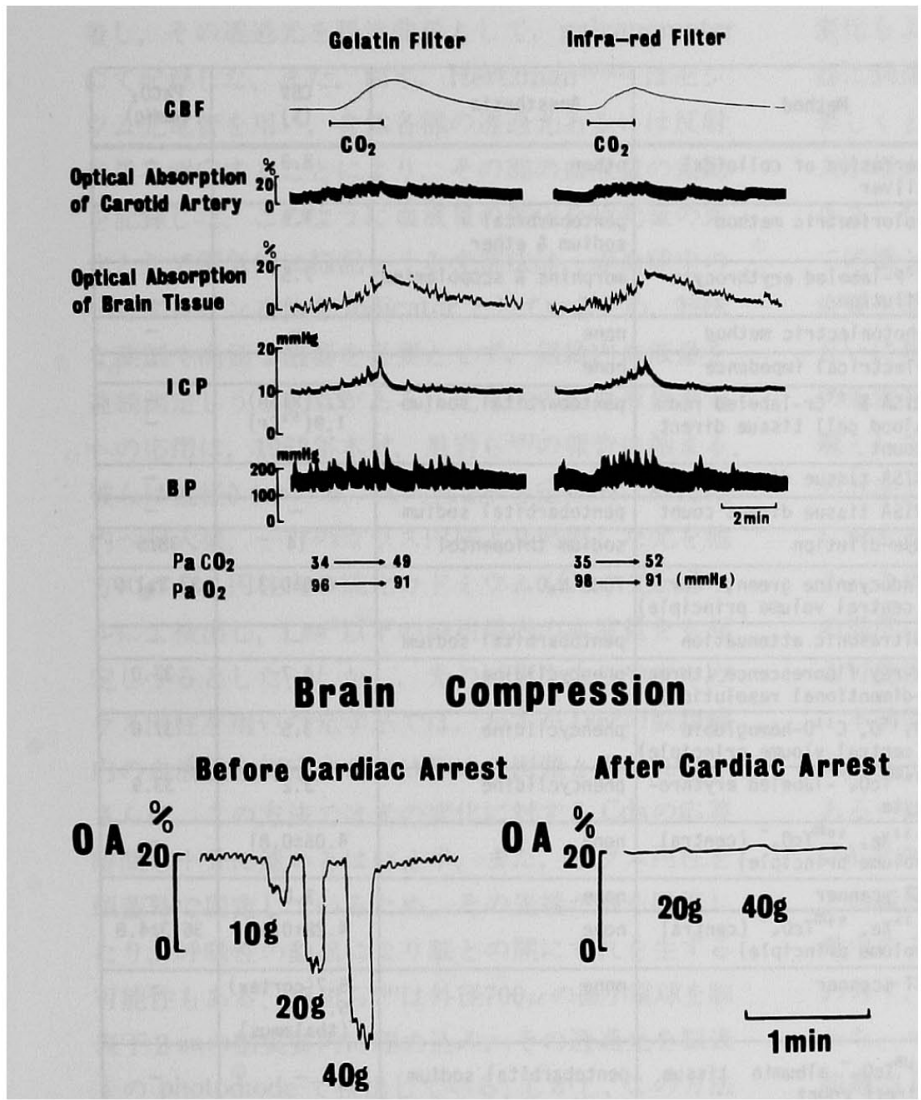

図18 10\%炭酸ガスの吸入により $\mathrm{Pa}$ $\mathrm{CO}_{2}$ は15-17mm Hg 增加し, $\mathrm{PaO}_{2}$ は5$7 \mathrm{mmHg}$ 減少した.この㮏, 脳血流量, 脳組織内 OA, 頭蓋内压は增加したが, 総頸動脈の OA は, gelatin filter と赤 外フィルターのいずれを用いて検出し ても変化はみられなかった（実験動物 №.37).

図19 生体脳では sensor B 上の鏵の 重さが増大するに従いOAは減少した が（左図，実験動物No.39），死体脳では OA は変化しなかった（右図，実験動 物No.39).

1928年,Wolff と Forbes ${ }^{28)}$ は骨空法を用い, 頭蓋 内圧六進時の脳表血管径を観察することにより脳血 管床の変化を調へた。.つづいて，1937年，Fog 29)30) は同しく骨空法にてネコの脳表血管径を観察し， epinephrine 投与, 腹部大動脈圧迫などにより，血圧 を上昇させると軟膜小動脈は収縮するが, 脱血し血 压を低下きせると拡張することを認めた。これより 彼は，血圧の上昇および下降に対する軟膜小動脈の 収縮拡張反応が生理的条件下においても脳血流を一 定に保つうえで重要な役割を果たしていることを指 摘した. 一方, Langfitt ${ }^{31)}$ は, サルに作成した頭蓋 内圧六進の各時期において norepinephrine を投与し たときの頭蓋内圧の変化から脳血管の緊張度を検討 した，その結果，頭蓋内圧が高度に上昇すると脳血 管緊張は低下し，増加した血液量はこらに頭蓋内圧 を上昇させると報告した。このように生理的状態, 病的状態をとわず脳循環動態を検討してゆく上では,
脳血流量のみならす脳血液量をも実際に測定するこ とが重要となる。しかし, 種々の脳血液量測定法が これまでに報告されてきたが（表 3 ），いまだ理想的 な方法はないといっても過言ではない。

従来, 脳血液量の測定方法としては, radioisotope を用いる方法がその主流をなしてきたが，それ以外 に, colloidal silver 脳組織内瀑度を定量する方法 ${ }^{32)}$ や脳組織内のへモグ

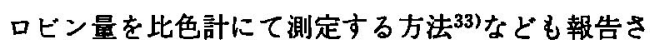
れている、しかし、これらの方法では，断頭時の artifactのため测定值のばらつきが大きく，しかも同 一個体で脳血液量を反復測定できない欠点がある. また経時的に脳血液量を測定する方法として, elect-

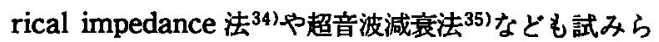
れている.しかし, impedance 值は, 䑈血流量を表 示すると考えるものや36), 脳内水分量, 電解質など の変化によっても大きく影響されるとする報告37)38399 もある.さらには, impedance の搏動性変動は, 呼 吸および血圧変動などによる脳実質の動きに基づく 
表 3 ．脳血液量测定方法に関する諸家の報告

\begin{tabular}{|c|c|c|c|c|c|}
\hline Author & Material & Method & Anesthesia & $\begin{array}{l}\text { CBV } \\
(x)\end{array}$ & $\begin{array}{l}\mathrm{PaCO}_{2} \\
(\mathrm{~mm}+\mathrm{Hg})\end{array}$ \\
\hline Weil et al. 32) & dog & $\begin{array}{l}\text { perfusion of colloidal } \\
\text { silver }\end{array}$ & ether & 8.3 & - \\
\hline White et al. 39) & cat & colorimetric method & $\begin{array}{l}\text { pentobarbital } \\
\text { sodium \& ether }\end{array}$ & 1.5 & - \\
\hline Nylin et al. 5 ) & human & $\begin{array}{l}\text { 32p-labeled erythrocyte } \\
\text { dilution }\end{array}$ & morphine \& scopolamine & 7.5 & - \\
\hline Kuroiwa et al. ${ }^{48)}$ (1962) & cat & photoelectric method & none & - & - \\
\hline Moskalenko et al.36) (1964) & human & electrical impedance & none & - & - \\
\hline Sklar et al. $\left.{ }^{6}\right) \quad$ (1968) & cat & $\begin{array}{l}\text { RISA }{ }^{51} \mathrm{Cr} \text {-labeled red } \\
\text { blood cell tissue direct } \\
\text { count }\end{array}$ & pentobarbital sodium & $\begin{array}{l}2.7(\text { RISA) } \\
1.9(51 \mathrm{Cr})\end{array}$ & - \\
\hline Risberg et a 1.7) (1969) & human & RISA tissue direct count & none & - & - \\
\hline Hasuo et al. 9 ) & dog & RISA tissue direct count & pentobarbital sodium & - & - \\
\hline Lowell et a 1. ${ }^{61}$ ) & rhesus monkey & dye-dilution & sodium thiopentol & 14 & $38 \pm 5$ \\
\hline Smith et a.$^{B}$ ) & goat & $\begin{array}{l}\text { indocyanine green, }{ }^{85} \mathrm{Kr} \\
\text { (central volume principle) }\end{array}$ & $70 \% \quad \mathrm{~N}_{2} \mathrm{O}$ & $4.8 \pm 0.3$ & $37.3 \pm 1.0$ \\
\hline Takaki et al. $\left.{ }^{35}\right)$ & dog & ultrasonic at tenuation & pentobarbital sodium & - & - \\
\hline Phelps et al. 42) (1973) & rhesus monkey & $\begin{array}{l}\text { x-ray fluorescence (three } \\
\text {-dimentional resolution) }\end{array}$ & phencyclidine & 4.7 & 37.0 \\
\hline Grubb et al. 11) & rhesus monkey & $\begin{array}{l}\mathrm{H}_{2}{ }^{15} 0, \mathrm{C}^{15} 0 \text {-hemoglobin } \\
\text { (central vloume principle) }\end{array}$ & phencyclidine & 3.5 & 37.0 \\
\hline Kuhl et al.12) & baboon & $\begin{array}{l}99 \mathrm{MTCO}_{4}{ }^{-} \text {- labeled erythro- } \\
\text { cyte }\end{array}$ & phencyclidine & 3.2 & 33.9 \\
\hline Mathew et al. ${ }^{10}$ & human & 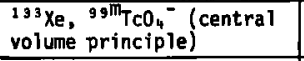 & none & $4.05 \pm 0.81$ & - \\
\hline Penn et al. 17) & human & CT scanner & none & 3.0 & - \\
\hline Aoyama 15) & $\begin{array}{c}\text { human } \\
\text { (normal man) }\end{array}$ & $\begin{array}{l}{ }^{133} \mathrm{Xe},{ }^{9 y i n} \mathrm{TcO}_{n}{ }^{-} \text {(central } \\
\text { volume principle) }\end{array}$ & none & $4.28 \pm 0.93$ & $36.3 \pm 4.8$ \\
\hline Ladurner et al.18) (1976) & human & CT scanner & none & $\begin{array}{l}5.7 \text { (cortex) } \\
5.1 \\
\text { (thalamus) }\end{array}$ & - \\
\hline Löfgren et al. ${ }^{13)} \quad$ (1976) & dog & $\begin{array}{l}9{ }^{11 \mathrm{~T}} \mathrm{CO}_{4}-\text { albumin tissue } \\
\text { direct count }\end{array}$ & pentobarbital sodium & - & - \\
\hline Voigt et al. ${ }^{14}$ ) & human & $\begin{array}{l}1{ }^{3 \mathrm{~m}} \text { In tissue direct } \\
\text { count }\end{array}$ & none & - & - \\
\hline Tomita et a 1.49 ) & cat & photoelectric method & pentobarbital sodium & - & - \\
\hline Present study & dog & photoelectric method & none & - & - \\
\hline
\end{tabular}

artifact に他ならないとする報告40)さえもみられ， impedance 法による脳血液量測定にはなお疑問の多 いところである．超音波減衰值に関し，高木 ${ }^{35}$ は種 々の負荷試験の結果, 超音波減衰が頭蓋内圧と同期 して変動したことから, 脳血液量を表示していると 結論したが,いずれの負荷試験においても超音波減 衰值は脳血流の変動とも同期しており，しかも脳血 管桩張時には, 受信器の周波数带域の超音波が脳血 流の増加により一見減少したかのように表示されう ることを考えれば, 超音波減衰值は血流の変化を反 映している可能性が強い41). Radioisotopeにより局 所脳血液量の変化を連続測定する場合には, back scatterのため局所表示性が十分でないという久点が あげられる。さらに, 131I-human serum albuminな どの plasma tracerを用いると，脳血管の透過性が 六進した際に血管外漏出を生じることも問題となる゙．
また, radioisotope を利用して, 脳血流量と脳循環 時間の積より血液量を求める central volume principleもしばしば用いられているが8)1011115)42)，この 方法とて，局所表示性に問題がある上に，脳血流量 と脳循環時間が同時に求められないことや，使用す る放射性医薬品の分配係数も病的脳組織では事実上 明らかにされていないなどの問題がある ${ }^{43)}$. 近年, 臨床例の脳血液量を noninvasiveに測定する方法と $し て, x$-ray fluorescence 法 ${ }^{42)}$ やCT-scanner を用

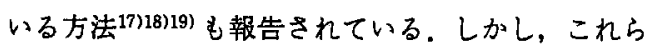
の方法では高価な機器を要するうえに使用されるヨ ード造影剤が破綻した血液脳関門より容易に血管外

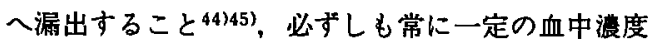
を保ちえないこと44)，一過性に血压や檤血流量を変 化させること46)，連続測定ができないことなどの久 点もあげられる。 
1938年, Matthes ${ }^{47)}$ は、オスラムランプを指に装 着し，その透過光を脈波曲線として，galvanometer にて記録した。また，同年，Hertzman'20121) はセシ ウム光電管を用い，身体各部の透過光あるいは反射 光量を測定することにより，その部の血液量の変動 を記録した。このように血液量の変化を吸光量の変 化として電気的に描記しうる光電法は，赤血球中の へモグロビン自体を indicator としているため，特殊 な薬剂や高価な機器を必要とせず，組織内血液量を 連続測定しうる利点がある. 光電法の脳血液量測定 への応用は，1962年木村，黒岩ら ${ }^{48)}$ の報告に始まる。 彼らは直径 $0.4 \mathrm{~mm}$ のガラス円柱 2 本を定位的に脳組織 内人刺入後，一方のガラス円柱より照射した光を他 方のガラス円柱内の硫化カドミウム (Cds) 光伝導セ ルにて検出し, $1 \mathrm{~mm}^{3}$ 以下の脳組織内の血液量をも測 定しうるとした。しかし，光の減衰を生じやすいが ラス円柱を用いた光学系では，わずか $1 \mathrm{~mm}^{3} の$ 脳組織 内の血液量を測定するのは極めて困難と思われる. さらにこの方法では光の変化に対する Cdsの応答 時間も十分に速いとはいえず，また，ガラス円柱を 頭蓋外で固定しているため，その先端が脳を压迫し たり，呼吸性の動摇により脳との間にずれを生ずる 可能性もある。富田ら ${ }^{49}$ は外径 $700 \mu$ の微小電球を脳 表下 $2 \mathrm{~mm}$ の脳実質内に埋め込み，その透過光を脳表 上の photodiode で検出している.しかし,この方法 でも脳組織に損傷を生ずることや光源と photodiode が固定されていないため種々の条件下では，その間 の距離が変動しうる恐れもある.

これまでの報告では脳組織中の血液量は 3〜4重 量\%といわれている1011112)17).したがって，光電法 によりこのわずかな脳血液量の変化を安定した状態 で感度よく測定するためには, 光源と光検出器の間 に存在する脳組織容積を可能な限り大きくし，しか も脳組織には吸收されにくく、へモグロビンにのみ 特異的に吸収される波長の光を用い，できるだけ明 るい光源で光検出器へ到達する光量を多くすること が重要である．しかし，明るい光源を用いれば，脳 組織が加熱される恐れもある。著者の予備実験では， glass fiber を用いて脳組織を照射した場合には照射 野の温度上界は0.5ㄷ 以下であったが, 微小電球では 約 5 趹上昇した。しかしこの微小電球をエポキ シ系樹脂とシリコンゴムにてつつみ，直接脳組織に 触れないようにすると光源直下の脳組織でもその温 度上㫒は $2{ }^{\circ} \mathrm{C}$ 以下にとどめえた，次に，光源と光検 出器の距離が大きくなれば，その間に存在する脳組
織容稓は增加し，血液量も多くなるため，血液量の 変化もよりとらえやすくなる，しかし反面, 光検出 器に到達する光量は減少するため, 増幅器の感度を 著しく上げねばならなくなる。その結果, noiseの混 入が増え, SN 比(目的信号の全雑音に対する比)は 小さくなり，OAの基線が動摇するため測定は極め て困難となる。このように, 光電法では感度よく血 液量を測定することと，安定して記録をとることは 互いに相反する．今回の著者の装置では，この両者 の条件をともに満足する光源と光検出器との間の距 離としては $8 \mathrm{~mm}$ が最適であった. 先に述べた富田ら の方法では, 微小電球が直接脳組織に接触しており, しかも血液量測定を行なう脳実質の厚さは $2 \mathrm{~mm}$ る。このため, 著者の方法に較べれば測定部脳組織 の温度は上昇しやすく、脳循環動態をも変化させう る可能性がある501511.

本装置にて脳血液量を测定するに際しては，へマ トクリット值が小さくなると赤血球による光の吸収 あるいは散乱が減少するため, 反射光の検出により OA を測定することが困難になるのではなかろうか との疑問が生じる。しかし，基礎実験において脳組 織中のみならず血液中でもへマトクリット值にかか からず，光は光源を中心に半円状に散乱した，すな わち、へマトクリット值が減少した際においても脳 組織内 OA は透過光，散乱光，反射光のいずれを用 いても検出可能との結果をえた，血液を含まない脳 組織には特有な吸収スペクトルが存在せず（図 7 ), in vivoの赛験で色美または生理的食塩水の注入によ $\eta$, 脳組織内 $O A$ か脳内血液の光吸収量とともに変 動したことは（図 9 ）,生体脳で認められる吸収スへ クトルが血液の光学特性に基づくものであることを 示唆している27)52). したがって脳血液量を的確に検 出するにはへモグロビンにより特異的に吸収される 波長の光を用いることが必要である。ここでへモグ ロビンは酸化へモグロビンと還元へモグロビンで異 なった吸収スぺクトルを示すため，もしへモグロビ ンの酸化度に影㸷されにくい光を選ふとすれば, 520 $\mathrm{m} \mu, 550 \mathrm{~m} \mu, 570 \mathrm{~m} \mu$ お 光を用いるべきである（図 7 )。これらのうち，520 $\mathrm{m} \mu, 550 \mathrm{~m} \mu, 570 \mathrm{~m} \mu$ などの可視領域の光は実際の測 定に際し SN 比が小さく，使用困難であった。しか し, gelatin filter と赤外フィルダーを用いれば, 680 $\mathrm{m} \mu$ 以上の波長の光をよく透過し，しかもこの波長 域の光は血液に吸収されやすく，脳組織をもよく透 過するという53)．さらに photodiode の分光感度特 
性が650m $\mu$ で最も高く，これは gelatin filterと赤外 フィルターの透光波長域に近いため、これらのフィ ルターを用いると安定した状態で OA を検出するこ とができた。

In vitroの実験では，血液量と透過光との間に Lambert-Beer の法則が成立したことから、こくわず かな血液量の変化をも比較的大きな光の変化として 表示しうることが確認できた.しかし Lambert. Beer の法則は, 溶液中で溶質分子間に相互作用のな い条件下においてのみ成立するという.ところが in vivoの条件下では血液の shear rateによって血 液の光学的密度が変化しうること ${ }^{54) 56)}$, sensor Bで

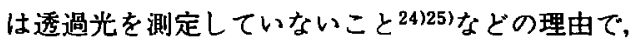
sensor B で測定した光量と血液量との間には必ずし も Lambert-Beer の法則は適用できない。このため 検知された光起電力の変化からは, 血液量の相対值 は求めえても絶対值を求めることはむずかしい。し かし, 脳血液量測定実験に際し同時に脳表血管を観 察してみると，脳表血管径にあまり変化を認めない ような負荷試験でも OAは明らかに変動し，光電法 を応用した本装置では確かにわずかな畄血液量の変 化をも大きなOAの変化としてとらえうるものと思 われた。

In vitroにおいては，血流速度の急激な変化によ り血液の光学的密度が変化するとの報告もみられる か5253)55), 今回の in vivoの実験では, $10 \% \mathrm{CO}_{2}$ 吸 入により脳血流量は增加しても，頸動脈内透過光に は変化を認めなかった。このことは, 生体内では急 激かつ著明な血流の変動がない限り，OAは血流の 影響をあまり受けないことを意味している。また本 装置により血夜量を測定する際には, 主として小動 脈，毛細血管，小静脈などの赤血球の aggregation を比較的生しにくい血管57を対象としているため, 測定中に血液の光学的密度が変化することも少なく， これに基づく artifact は入りにくいものと思われる.

In vivoにおける各種負荷試験では, 脳血液量と脳 血流量はともに平行して変化することも多いが，頸 静脈圧迫では脳血流量が減少するにもかかわらず脳 血液量は增加する。この時 OA が增加した（図12） ことから，OA は脳血流量よりもむしろ脳血液量の 変化を表現しているものと考えられた。

本装置で測定した脳組織内 OA は，今回の実験で 検討した範囲では, sensor 下面の脳構筑（図11）,脳 組織中水分量および頭蓋内圧（図17）が変動しても ほぼ一定であった。 また, 生体脳で sensor B を脳
表に压迫するとOAは減少したが, 死体脳では変化 しなかった（図19）.これは生体脳の sensor下におい て，脳血管が圧迫され虚脱をきたすけれども58，死 体脳では血管がすでに虚脱しているため脳組織圧の 影罂のみを反映しているものと考えられた，このこ とから OA は脳組織压よりも脳血管床の変化を反映 しているものと思われた。ささらにOA は脳血管拡張 作用を有する炭酸ガス吸入 ${ }^{59)}$, Papaverine hydrochloride 投与 ${ }^{59)}$, 頸静脈圧迫で增加し, 脳血管の収 縮を生ずる過呼吸599により減少した。しかもその增 堿は頭蓋内圧と同期した変動を示していた，従来， Monro-Kellie's doctrineにもみられるように, 頭蓋内 圧は頭蓋内の三構成要素である脳組織, 脳脊髄液, 脳血管床内血液のそれぞれが占める容積の総和とし て表現される60).これら三者のうちで比較的短時間 にその容積変化を生ずるものは咀液量と脳血液量で ある。しかし，脳血管床容積の変動をきたす各種負 荷試験の結果, 頭蓋内圧とOA が同期して変化した ことと, 先に述べた頸静脈圧迫の実験結果から, 本 法により測定しえたOAは脳血液量を表現している ものと結論してもさしつかえなかろう。

\section{VI結語}

局所㨫血液量を経時的に観察，記録することを目 的として, 光電法を利用した㨫血液量測定装置を試 作し, in vitroおよび in vivoの基礎実験にて, 装置 の感度, 安定性の面では一応満足しうる結果をえた。 本法の短所としては, (1). 脳血液量の絶对値が測定 できないこと，(2). 外部の光を遮閉しなければなら ないこと，(3. 脳深部の血液量は測定困難であるこ となどの問題をなお残している。しかし，長所とし ては，(1)．特殊な施設，高価な機器を必要としない こと，(2)，血色素自体を indicator として比較的簡 单に局所脳血液量を連続的に測定できること, (3). 生理的食塩水または色素の注入により循環時間も求 めうること，(4).この装置ではさらに頭蓋内圧も同 時に測定できることなどの特徽があげられる、今後, 頭蓋内压元進時の脳循環動態を研究してゆくうえでも 使用できる有用な方法と考えられる。

稿を終るに臨み、御熙篤なる御指導と御鞭撻を睗った 恩師西本詮教授に深謝するとともに，終始多大な御指導 を頂いた松本皓先生に謝意を表します。また本研究に御 協力頂いた秋岡達郎先生, 二宫一彦先生, 西本健先生, 藤本俊一郎先生ならびに岡山大学理学部山下信彦先生に 
心から厚くお礼申し上げます。

なお, 本論文の要旨は, 第52回日本医科器械学会大会,
第36回日本媨神経外科学会総会, 第20回脳循䍗代謝研究

会，第19回日本神経学会総会において発表した。

\section{文献}

1. Evans, J.P. and Scheinker, I.M.: Histologic studies of the brain following head trauma. J. Neurosurg. 2, 306-314, 1945.

2 . Langfitt, T.W., Weinstein, J.D., Sklar, F.H., Zaren, H.A. and Kassell, N.F.: Contribution of intracranial blood volume to three forms of experimental brain swelling. Johns Hopkins Med. J. 122, 261 $-270,1968$.

3. Langfitt, T.W., Tannanbaum, H.M. and Kassel, N.F.: The etiology of acute brain swelling following experimental head injury. J. Neurosurg. 24, 47-56, 1966.

4. 前田 稳：急性脳腫脹の発生機序および治療に関する実験的研究. 日外会誌, 73, 93-103, 1972.

5 . Nylin, G., Hedlund, S. and Regnström, O.: Studies of the cerebral circulation with labeled erythrocytes in healthy man. Circ. Res. 9, 664-674, 1961.

6. Sklar, F.H., Burke, E.F.Jr. and Langfitt, T.W.: Cerebral blood volume: Values obtained with ${ }^{51} \mathrm{Cr}$ labeled red blood cells and RISA. J. Appl. Physiol. 24. 79-82, 1968.

7. Risberg, J., Lundberg, N. and Ingvar, D.H.: Regional cerebral blood volume during acute transient rises of the intracranial pressure (plateau waves). J. Neurosurg. 31, 303-310, 1969 .

8. Smith, A.L., Neufeld, G.R., Ominsky, A.J. and Wollman, H.: Effect of arterial $\mathrm{CO}_{2}$ tension on cerebral blood flow, mean transit time, and vascular volume. J. Appl. Physiol. 31, 701-707, 1971.

9.蓮尾道明：急性頭蓋内圧上昇時の脳循環動態：特に䐉血流と脳血管床内血液量の変動について. 脳と神経, 23, 1517-1526, 1971.

10. Mathew, N.T., Meyer, J.S. and Otto, E.O.: Increased cerebral blood volume in benign intracranial hypertension. Neurology, 25, 646-649, 1975.

11. Grubb, R.L.Jr., Raichle, M.E., Phelps, M.E. and Ratcheson, R.A.: Effects of increased intracranial pressure on cerebral blood volume, blood flow, and oxygen utilization in monkeys. J. Neurosurg. 43, 385-398, 1975.

12. Kuhl, D.E., Reivich, M., Alavi, A., Nyary, I. and Staum, M.M.: Local cerebral blood volume determined by three-dimensional reconstruction of radionuclide scan data. Circ. Res. 36, 610-619, 1975.

13. Lögren, J. and Zwetnow, N.N.: Intracranial blood volume and its variation with changes in intracranial pressure, In Intracranial Pressure III, ed. J.W.F. Beks, D.A. Bosch, and M. Brock, SpringerVerlag, Berlin-Heidelberg-New York, pp. 25-28, 1976.

14. Voigt, K. and Greitz, T.: Cerebral blood volume alterations during fractional pneurnoencephalography. Am. J. Roentgenol. 126, 582-592, 1976.

15. 青山 喬：脳硬塞症例の非閉塞部位における脳循環に関する研究. 脳と神経, 28, 1207-1214, 1976.

16. 竹山英二, 上野一郎，高良英一，馬場元媇，神保 実，喜多村孝一：RI 静注法による脳循環時間および脳 血管床量左右差の検討. 脳と神経，30，853-859，1978.

17. Penn, R.D., Walser, R. and Ackerman, L.: Cerebral blood volume in man; computer analysis of a computerized brain scan. J. Am. Med. Assoc. 243, 1154-1155, 1975.

18. Ladurner, G., Zilkha, E., Iliff, L.D., Du Boulag, G.H. and Marshall, J.: Measurement of regional cerebral blood volume by computerized axial tomography. J. Neurol. Neurosurg. Psychiatry. 39, 152-158, 1976.

19. 北野郁夫，賀来素之，松角康彦：Computer 処理によるCT scan の局所脳血液量の測定一その批判と対策 
一. 神経外科, 18, 473-482, 1978 .

20. Hertzman, A.B.: Comparative estimation of blood supply of skin area from photoelectrically recorded volume pulse. Proc. Soc. Exp. Biol. Med. 38, 562-564, 1938.

21. Hertzman, A.B.: The blood supply of various skin areas as estimated by the photoelectric plethysmograph. Am. J. Physiol. 124, 328-340, 1938.

22. Hertzman, A.B. and Dillon, J.B.: Selective vascular reaction patterns in the nasal septum and skin of the extremities and head. Am. J. Physiol. 127, 671-684, 1939.

23. Hertzman, A.B. and Dillon, J.B.: Applications of photoelectric plethysmography in peripheral vascular disease. Am. Heart J. 20, 750-761, 1940.

24. 久山秀幸, 藤本俊一郎, 西本 健, 秋岡達郎, 松本 皓, 西本 詮：光電法による局所脳血液量測定. 医 科器械学雑誌, $47,74-77,1977$.

25. 久山秀幸, 藤本俊一郎, 西本 健, 二宮一彦, 秋岡達郎, 松本 皓, 西本 詮：光電法に上る局所脳血液 量測定の試み。神経外科, 18, 655-664, 1978.

26. 鉿木光雄：へモグロビン，ミオグロビン。血色素の生理と臨床, 監修, 上代皓三, 中尾喜久, 医学書院, 東京, pp. 184-219, 1958.

27. 三島好雄：四肢循環状態の検查法. 医学者のためのエレクトロニクス, 監修, 大島良雄, 南江堂, 東京, pp. 327-357, 1964 .

28. Wolff, H.G. and Forbes, H.S.: The cerebral circulation. 5. Observations of the pial circulation during changes in intracranial pressure. Arch. Neurol. Psychiatr. 20, 1035-1047, 1928.

29. Fog, M.: Cerebral circulation, The reaction of the pial arteries to a fall in blood pressure. Arch. Neurol. Psychiatr. 37, 351-364, 1937.

30. Fog. M.: Cerebral circulation, II. Reaction of pial arteries to increase in blood pressure. Arch. Neurol. Psychiatr. 41, 260-268, 1939.

31. Langfitt, T.W., Weinstein, J.D. and Kassell, N.F.: Cerebral vasomotor paralysis produced by intracranial hypertension. Neurology 15, 622-641, 1965.

32. Weil, A., Zeiss, F.R. and Cleveland, D.A.: The determination of the amount of blood in the central nervous system after injection of hypertonic solutions. Am. J. Physiol. 98, 363-367, 1931.

33. White, J.C., Verlot, M., Selverstone, B. and Beecher, H.K.: Changes in brain volume during anesthesia: The effects of anoxia and hypercapnia. Arch. Surg. 44, 1-21, 1942.

34. Moskalenko, Yu.E., Cooper, R., Crow, H.J. and Walter, G.: Variations in blood volume and oxygen availability in the human brain. Nature 202, 159-161, 1964 .

35. 高木 偉：急性脳腫脹の本態及び発生機序に関する実験的研究. 日外会誌, 77, 649-661, 1976.

36. 桑原武夫：頭の電気容積脈波及びインピーダンス脈波について．脳と神経，11，209-223，1959.

37. Go, K.G., van der Veen, P.H., Ebels, E.J. and van Woudenberg, F.: A study of electrical impedance of oedematous cerebral tissue during operations: Correlation of impedance with water and clectrolyte content and with histology. Acta Neurochir. 27, 113-124, 1972.

38. Cooley, W.L. and Lehr, J.L.: Electrical impedance fluctuation as an indicator of fluid volume changes in a living organism. Bio-Med. Eng. 7, 313-315, 1972.

39. Gamache, F.W.Jr., Dold, G.M. and Myers, R.E.: Changes in cortical impedance and EEG activity induced by profound hypotension. Am. J. Physiol. 228, 1914-1975.

40. 桜井芳明：脳血流動態と Impedance Plethysmography. 脳と神経、23，1505-1515，1971.

41. 宮崎 学：超音波 Doppler 法による脳循環測定．脳と神経，27，1149-1155，1975.

42. Phelps, M.E., Grubb, R.L.Jr. and Ter-Pogossian, M.M.: Correlation between $\mathrm{PaCO}_{2}$ and regional cerebral blood volume by X-ray fluorescence. J. Appl. Physiol. 35, 274-280, 1973.

43. 上村和夫, 山口昂一, 高橋 弘。沓沢尚之, 川上倖司：RIによる脳循環動態の測定. 綜合臨床, 20, 1660 
-1674, 1971.

44. Gado, M.H., Phelps, M.E. and Coleman, R.E.: An extravascular component of contrast enhancement in cranial computed tomography. Part I: The tissue-blood ratio of contrast enhancement. Radio$\log y 117,589-593,1975$.

45. Gado, M.H., Phelps, M.E. and Coleman, R.E.: An extravascular component of contrast enhancement in cranial computed tomography. Part II: Contrast enhancement and the blood-tissue barrier. Radiology 117, 595-597, 1975.

46. Phelps, M.E. and Kuhl, D.E.: Pitfalls in the measurement of cerebral blood volume with computed tomography. Radiology 121, 375-377, 1976 .

47. Matthes, K. and Haurs, W.: Lichtelektrische Plethysmogramme. Klin. Wschr. 17, 1211-1213, 1938.

48. 木村敏夫，黒岩晋太郎，野口拓郎：大脳皮質の血流動態と光電 plethysmography. 未梢循環とその病態生 理，未梢循環研究会編，東京大学出版会，東京，pp. 327-335，1967.

49. 富田 稔, 後藤文男, 佐藤 勉, 天野隆弘, 棚橋紀夫, 田中耕太郎, 山本正博：ネコ脳組織血管床におけ る 4-6 cpm 律動的変動とその消長. 第18回日本神経学会総会プログラム抄録, 名古屋, pp, 390, 1977.

50. Harris, A.B., Erickson, L., Kendig, J.H., Mingrino, S. and Coldring, S.: Observations on selective brain heating in dogs. J. Neurosurg. 19, 514-521, 1962.

51. Raisis, J.E., Kindt, G.W. and McGillicuddy, J.E.: The effect of temperature on cerebrovascular resistance and cerebral metabolism in the primate. In Blood Flow and Metabolism in the Brain, ed. M. Harper, B. Jennett, D. Miller, and J. Rowan, Churchill Livingstone, Edinburgh-London-New York, pp, $11,36-37,1975$.

52. 金井 竟, 酒本勝之, 丹羽宗弘, 坂本義貞：流れている血液の光学特性. 第16回 日本 ME 学会大会論文集, 日本 ME 学会, 東京, pp. 486-487, 1977.

53. 亘 弘，田中義文：皮膚反射スペクトルの持つ情報。分光研究，22：163-164，1973.

54. 黒田嘉一郎：流動透光性と赤血球。日本血液学会雑誌，19，387-406，1956.

55. Klose, H.J., Volger, E., Brechtelsbauer, H., Heinich, L. and Schmid-Schönbein, H.: Microrheology and light transmission of blood. I. The photometric effects of red cell aggregation and red cell orientation. Pflugers Arch. 333, 126-139, 1972.

56. 富田 稔：脳血管抵抗一inertial pressure loss と血液の non-Newtonian性の影響について一. 脈管学, 16, 193一 $202,1976$.

57. Wells, R.E.Jr.: Rheology of blood in the microvasculature. N. Engl. J. Med. 270, 832-839, 1964 .

58. Numoto, M. and Donaghy, R.M.P.: Effects of local pressure on cortical electrical activity and cortical vessels in the dog. J. Neurosurg. 33, 381-387, 1970.

59. Sokoloff,L.: The action of drugs on the cerebral circulation. Pharmacol. Rev. 11, $1-85,1959$.

60. 池山 淳, 前田 成, 永井 㯺：頭蓋内圧六進の病態; open cavity 加ら closed cavity への移行についての考察。 脑卒中, 編集, 大根田玄寿, 庽山正邦，佐野圭司，鈴木二郎，田崎義昭，第 3 巻, 脳循環, にゅーろん社, 川崎, pp. 105-112, 1976.

61. Lowell, H.M. and Bloor, B.M.: The effect of increased intracranial pressure on cerebrovascular hemodynamics. J. Neurosurg. 34, 760-769, 1971. 
The cerebral blood volume (CBV) is an important parameter of cerebral hemodynamics. However, measurement of CBV has been difficult. We have devised a photoelectric method for measurement of regional CBV.

The sensor of the apparatus was made of three components; a microlamp, a photodiode to which an infra-red filter was attached, and a polyethylene balloon, or polyethylene catheter with its tip open for intracranial pressure (ICP) measurement. These were pasted with silicon rubber. The sensor was applied to the brain surface to measure the intensity of the optical absorption (OA) of hemoglobin in the brain tissue. OA remained nearly constant despite various alterations in cerebral blood flow (CBF), brain tissue pressure, and water content of the brain. Both $\mathrm{OA}$ and ICP increased during vasodilatation induced by $\mathrm{CO}_{2}$ inhalation, compression of the jugular veins, or intravenous injection of Papaverine hydrochloride. Both decreased during vasoconstriction induced by hyperventilation or severe arterial hypotension. These results suggest that $O A$ reflects changes of $C B V$.

The disadvantages of this method are that the absolute CBV and the CBV in the deeper brain tissues can not be measured and that the operative field has to be kept dark. However, this method has several advantages;

(1) Regional CBV is continuously measured without radionuclide or other specific indicators.

(2) This method does not require a skilled technique.

(3) The cerebral transit time can be measured by injection of saline or other indicators into the right brachial artery.

(4) This device can also measure ICP. 